\title{
Review
}

\section{An Overview of Bioactive Flavonoids from Citrus Fruits}

\author{
Mohamed Addi ${ }^{1, *(\mathbb{D}}$, Amine Elbouzidi ${ }^{1}\left(\mathbb{D}\right.$, Malika Abid $^{1}$, Duangjai Tungmunnithum ${ }^{2,3,4} \mathbb{C}^{\circ}$, Ahmed Elamrani ${ }^{1}(\mathbb{D}$ \\ and Christophe Hano $2,3, *$ (D) \\ 1 Laboratoire d'Amélioration des Productions Agricoles, Biotechnologie et Environnement (LAPABE), \\ Faculté des Sciences, Université Mohammed Premier, Oujda 60000, Morocco; \\ amine.elbouzidi@ump.ac.ma (A.E.); m.abid@ump.ac.ma (M.A.); a.elamrani1@ump.ac.ma (A.E.) \\ 2 Laboratoire de Biologie des Ligneux et des Grandes Cultures, INRAE USC1328, Campus Eure et Loir, \\ Orleans University, 28000 Chartres, France; duangjai.tun@mahidol.ac.th \\ 3 Le StudiumInstitue for Advanced Studies, 1 Rue Dupanloup, 45000 Orléans, France \\ 4 Department of Pharmaceutical Botany, Faculty of Pharmacy, Mahidol University, Bangkok 10400, Thailand \\ * Correspondence: m.addi@ump.ac.ma (M.A.); hano@univ-orleans.fr (C.H.)
}

check for updates

Citation: Addi, M.; Elbouzidi, A. Abid, M.; Tungmunnithum, D.; Elamrani, A.; Hano, C. An Overview of Bioactive Flavonoids from Citrus Fruits. Appl. Sci. 2022, 12, 29. https: //doi.org/10.3390/app12010029

Academic Editors: Giorgia Spigno and Luca Mazzoni

Received: 20 October 2021

Accepted: 19 December 2021

Published: 21 December 2021

Publisher's Note: MDPI stays neutral with regard to jurisdictional claims in published maps and institutional affiliations.

Copyright: (c) 2021 by the authors. Licensee MDPI, Basel, Switzerland. This article is an open access article distributed under the terms and conditions of the Creative Commons Attribution (CC BY) license (https:// creativecommons.org/licenses/by/ $4.0 /)$.

\begin{abstract}
Citrus species are one of the world's popular fruit crops, cultivated all over the world for their economic and nutritional values. Citrus, like other fruits and vegetables, are an important source of several antioxidant molecules (polyphenols, ascorbic acid, and carotenoids) that can inhibit the harmful effects of free radicals on the human body; due to their functional values and healthpromoting properties, Citrus species are considered valuable fruits not only in agri-food industry, but also in pharmaceutical industry. Flavonoids are among the major constituents of polyphenols found in different parts of Citrus fruits (skin, peels, seed, pulp membrane, and juice). Flavonoids have different biological properties (antiviral, antifungal, and antibacterial activities). Several studies have also shown the health-related properties of Citrus flavonoids, especially antioxidant, anticancer, antiinflammation, anti-aging, and cardiovascular protection activities. In the present review, attempts are made to discuss the current trends of research on flavonoids in different Citrus species.
\end{abstract}

Keywords: Citrus genus; bioactive molecules; flavonoids; therapeutic effects; extraction methods

\section{Introduction}

Citrus genus is one of the world's leading fruit crops cultivated for food processing as well as fresh juice production. The genus Citrus belongs to the family Rutaceae, containing several species such as orange types, sweet and sour oranges, lemon, tangerines (mandarins), and tangors. Each species or hybrid cross has one or more varieties. Besides being a rich source of vitamins $\mathrm{A}, \mathrm{C}$, and E, mineral elements, and dietary fibers, Citrus fruits are a great source of secondary metabolites, such as polyphenols and terpenoids [1]. Flavonoids and phenolic acids are the main classes of phenolic compounds found in Citrus fruits [2]. In general, the fruit skin contains a higher concentration of antioxidant substances than the other parts of the fruit [3]. Citrus flavonoid contents and profiles vary significantly from one species to another [4]. Citrus peel, which represents between $50 \%$ and $65 \%$ of the total weight of the fruits, is a rich source of bioactive compounds, including natural antioxidants such as flavonoids [5]. Several studies showed that Citrus flavonoids are found to have anti-inflammatory, anti-cancer, anti-bacterial, anti-aging, and cardiovascular protection activities [6,7].

Our objective here is to provide an overview of the structure, class, and origin of the diverse classes of Citrus flavonoids. In addition, we attempt to summarize data from the scientific literature and present values on the flavonoids in some Citrus species and their health-promoting properties.

\section{The Citrus Taxonomy}

Citrus is a terrestrial flowering plant that belongs to the family of Rutaceae, the subfamily of Aurantioideae, the tribe of Citreae, and the subtribe of Citrinae (Table 1) [8]. 
The genus Citrus contains many kinds or types of species that differ regarding their fruits, flowers, leaves, and twigs. The taxonomy of the genus Citrus is complex and controversial, mainly because of sexual compatibility between species and genera, and polyembryony that fixes and reproduces the maternal genotypes. The classification criteria are mainly based on morphological characteristics. There are two principal systems of Citrus taxonomy: Swingle and Reece's (1967) system [9], and Tanaka's (1977) system [10]. These two authors presented two different concepts of classification. Swingle was able to identify only 16 species of Citrus, while Tanaka defined 156 species. The classification of Swingle and Reece (1967), based on the edibility of fruits, distinguishes between the subgenus of Eucitrus, where all cultivated taxa are grouped, and the subgenus of Papeda [9]. The last-mentioned subgenus consists of six species: C. micrantha Wester (currently a synonym of C. hystrix DC.), C. ichangensis Swing (currently a synonym of Citrus cavaleriei H.Lév. ex Cavalerie), C. hystrix DC., C. latipes (Swingle) Yu. Tanaka, C. celebica Koord (currently a synonym of Citrus hystrix DC.) and C. macroptera Montr. (Satkara) (currently a synonym of Citrus hystrix DC.).

Table 1. The subfamily of Aurantioideae [8,11].

\begin{tabular}{|c|c|c|c|c|}
\hline Tribe & $\begin{array}{c}\text { Subtribe } \\
\text { (Subtribe Group) }\end{array}$ & Genus & $\begin{array}{l}\text { Number of } \\
\text { Species }\end{array}$ & Origin \\
\hline 2 Tribes & 6 Subtribes & 33 Genera & 203 Species & - \\
\hline \multirow{5}{*}{ Clauseneae } & Micromelinae & Micromelum & 9 & S.E. Asia, Oceania \\
\hline & \multirow{3}{*}{ Clauseninae } & Glycosmis & 35 & S.E. Asia, Oceania \\
\hline & & Clausena & 23 & S. Asia, Oceania \\
\hline & & Murraya & 11 & S. and S.E. Asia, Oceania \\
\hline & Merrillinae & Merrillia & 1 & S.E. Asia \\
\hline \multirow{21}{*}{ Citreae } & \multirow{8}{*}{ Triphasiinae } & Wenzelia & 9 & Oceania \\
\hline & & Monathocitrus & 1 & Oceania \\
\hline & & Oxanthera & 4 & Oceania \\
\hline & & Merope & 1 & S.E. Asia, Oceania \\
\hline & & Triphasia & 3 & S.E. Asia, Oceania \\
\hline & & Pamburus & 1 & S. and S.E. Asia, Oceania \\
\hline & & Luvugna & 12 & S. and S.E. Asia, Oceania \\
\hline & & Paramignya & 15 & S. and S.E. Asia, Oceania \\
\hline & \multirow{5}{*}{ Citrinae (group A) } & Severinia & 6 & S. China, S.E. Asia \\
\hline & & Pleiospermium & 5 & S. Asia, Oceania \\
\hline & & Burkillanthus & 1 & S.E. Asia, Oceania \\
\hline & & Limnocitrus & 1 & S.E. Asia \\
\hline & & Hesperethusa & 1 & S. and S.E. Asia \\
\hline & \multirow{2}{*}{ Citrinae (group B) } & Citropsis & 11 & Central Africa \\
\hline & & Atalantia & 11 & S. and S.E. Asia \\
\hline & \multirow{6}{*}{ Citrinae (group C) } & Fortunella & 4 & S. China \\
\hline & & Eremocitrus & 1 & Australia \\
\hline & & Poncirus & 1 & Central and N. China \\
\hline & & Clymenia & 1 & Oceania \\
\hline & & Microcitrus & 6 & Australia \\
\hline & & Citrus & 16 & S. and S.E. Asia, S. China \\
\hline
\end{tabular}


Table 1. Cont.

\begin{tabular}{ccccc}
\hline \multirow{2}{*}{ Tribe } & $\begin{array}{c}\text { Subtribe } \\
\text { (Subtribe Group) }\end{array}$ & Genus & $\begin{array}{c}\text { Number of } \\
\text { Species }\end{array}$ & Origin \\
\hline \multirow{2}{*}{ Balsmocitrinae } & Swingela & 1 & Philippines \\
\cline { 2 - 4 } & Aeggle & 1 & India \\
\cline { 2 - 4 } & Afraegle & 4 & W. Africa \\
\cline { 2 - 4 } & Balsamocitrus & 1 & Uganda \\
\cline { 2 - 4 } & Limonia & 1 & S. and S.E. Asia \\
\cline { 2 - 4 } & Feroniella & 3 & S.E. Asia \\
\hline
\end{tabular}

The subgenus Eucitrus encompasses ten cultivated species: C. medica L. (citron), C. aurantium L. (sour orange), C. sinensis (L.) Osbeck (sweet orange), C. limon (L.) Osbeck (lemon), Citrus aurantiifolia (Christm.) Swingle (key lime), C.maxima (Burm.) Merr. (pomelo), C. paradisi Macfad. (grapefruit), C. reticulata Blanco (mandarin orange), C. indica Yu.Tanaka (Indian wild orange), and C.tachibana (Tachibana orange), which is currently a synonym of C. reticulata Blanco.

Tanaka's taxonomy is much more detailed than that adopted by Swingle and Reece. Indeed, Tanaka subdivided the genus Citrus into two subgenera species: Archicitrus and Metacitrus. Thus, the main differences between Swingle and Tanaka classification concern the recognition of Citrus hybrids, cultivars, bud spots, and variant taxa as true botanical species. Tanaka (1977) considered them as absolute botanical species; on the other hand, Swingle and Reece did not accept them as true taxonomic species.

\section{Citrus Flavonoids: Structure, Classification and Biosynthesis}

\subsection{Structure and Classification of Flavonoids from Citrus}

Flavonoids are an important class of natural products; particularly, they belong to polyphenol compounds and are synthesized by plants via primary or secondary metabolisms that protect against short-term or long-term threats and play a major function in plant development and reproduction [12]. Flavonoids are found widespread throughout the plant kingdom and are associated with many health benefits [13]. They are a major class of phytochemicals discovered in citrus fruits, especially in peels, pulp, and seeds. Flavonoids are small molecular weight polyphenolic substances that have the same basic skeleton of fifteen carbons (C6-C3-C6), consisting of two phenyl rings (A and B) connected by a heterocyclic pyran or pyron ring $(\mathrm{C})$ in the center, depending on their substituents. Flavonoids are subdivided into flavanols, anthocyanidins, flavanones, flavones, and chalcones [14]. The generic flavonoid structure and the numbering system used to distinguish the carbon positions around the molecule are shown in Table 2. The three phenolic rings that make up the flavonoid molecule are called pyran rings. Citrus flavonoids are divided into three principal types, namely, flavanones, flavones, and flavonols [15]. In Table 2, the classification of Citrus flavonoids and the chemical structures of major flavonoids are presented. The main flavonoids found in Citrus species are hesperidin, narirutin, naringin and eriocitrin. 
Table 2. Basic structures of Citrus flavonoid subclasses [16].

\begin{tabular}{|c|c|c|c|}
\hline Citrus Flavonoids & Structure Backbone & & Examples \\
\hline \multirow{4}{*}{ Flavanones } & & \multirow{2}{*}{ Hesperetin } & $\mathrm{R}_{1}=\mathrm{O}-\mathrm{CH}_{3}$ \\
\hline & & & $\mathrm{R}_{2}=\mathrm{OH}$ \\
\hline & & \multirow{2}{*}{ Naringenin } & $\mathrm{R}_{1}=\mathrm{OH}$ \\
\hline & & & $\mathrm{R}_{2}=\mathrm{H}$ \\
\hline \multirow{6}{*}{ Flavanones glycosides } & & \multirow{3}{*}{ Narirutin } & $\mathrm{R}_{1}=\mathrm{O}-\mathrm{CH}_{3}$ \\
\hline & & & $\mathrm{R}_{2}=\mathrm{H}$ \\
\hline & & & $\mathrm{R}_{3}=7-O$-rutinoside \\
\hline & & \multirow{3}{*}{ Naringin } & $\mathrm{R}_{1}=\mathrm{OH}$ \\
\hline & & & $\mathrm{R}_{2}=\mathrm{H}$ \\
\hline & & & $\mathrm{R}_{3}=\mathrm{O}-7-$ Rhamnoglucoside \\
\hline \multirow{4}{*}{ Flavones } & & \multirow{2}{*}{ Apigenin } & $\mathrm{R}_{1}=\mathrm{OH}$ \\
\hline & & & $\mathrm{R}_{2}=\mathrm{R}_{3}=\mathrm{H}$ \\
\hline & & \multirow{2}{*}{ Luteolin } & $\mathrm{R}_{1}=\mathrm{R}_{2}=\mathrm{OH}$ \\
\hline & & & $\mathrm{R}_{3}=\mathrm{H}$ \\
\hline \multirow{4}{*}{$\begin{array}{l}\text { Polymethoxylated } \\
\text { Flavones }\end{array}$} & \multirow[b]{4}{*}{$\mathrm{OCH}_{3}$} & \multirow{2}{*}{ Nobiletin } & $\mathrm{R}_{1}=\mathrm{H}$ \\
\hline & & & $\mathrm{R}_{2}=\mathrm{R}_{3}=\mathrm{OCH}_{3}$ \\
\hline & & \multirow{2}{*}{ Tangeretin } & $\mathrm{R}_{1}=\mathrm{R}_{3}=\mathrm{H}$ \\
\hline & & & $\mathrm{R}_{2}=\mathrm{OCH}_{3}$ \\
\hline \multirow{3}{*}{ Flavonols } & & Quercetin & $\mathrm{R}_{1}=\mathrm{R}_{2}=\mathrm{R}_{3}=\mathrm{OH}$ \\
\hline & & \multirow{2}{*}{ Kaempferol } & $\mathrm{R}_{1}=\mathrm{R}_{3}=\mathrm{OH}$ \\
\hline & $\mathbf{R}_{3}$ & & $\mathrm{R}_{2}=\mathrm{H}$ \\
\hline
\end{tabular}

\subsection{Biosynthesis of Flavonoids}

The flavonoid pathway is preceded by the general phenylpropanoid pathway, in which three enzymes are involved in the conversion of the amino acid phenylalanine to 4-coumaroyl-CoA. the first enzyme, phenylalanine ammonia lyase (PAL:EC 4.3.1.24) catalyzes the conversion of the amino acid phenylalanine to trans-cinnamic acid, with the release of ammonia (NH3), then the two other enzymes (the enzyme cinnamate 4- 
hydroxylase (C4H:EC 1.14.14.91), followed by 4-coumarate-CoA ligase (4CL:EC 6.2.1.12)), catalyze the reaction that leads to obtain 4-coumaroyl-CoA, which is an important precursor in the flavonoid pathway [12,13]. The biosynthesis of flavonoids is originated from the phenylpropanoids pathway and initiated by two precursors named malonyl-CoA and $p$ coumaroyl-CoA (Figure 1). After the condensation of three acetate units from malonyl-CoA with one molecule of $p$-coumaroyl-CoA, naringenin chalcones are formed. Naringenin chalcone, a major pigment of many flowers, leaves and fruits, is converted to naringenin by chalcone isomerase $(\mathrm{CHI})$ or non-enzymatically in vitro $[14,15]$. This reaction catalyzed by chalcone synthase (CHS:EC 2.3.1.74) is thought to be the key regulatory step in the synthesis of flavonoids. It catalyzes the stereospecific isomerization of chalcones to their corresponding (2S)-flavanones via an acid base catalysis mechanism; the unstable chalcone form is normally isomerized by the enzyme chalcone isomerase (CHI:EC 5.5.1.6) to form the structural precursors for a broad range of flavonoids, such as flavonols, flavanones, anthocyanin glycosides and other derived compounds (Figure 1).

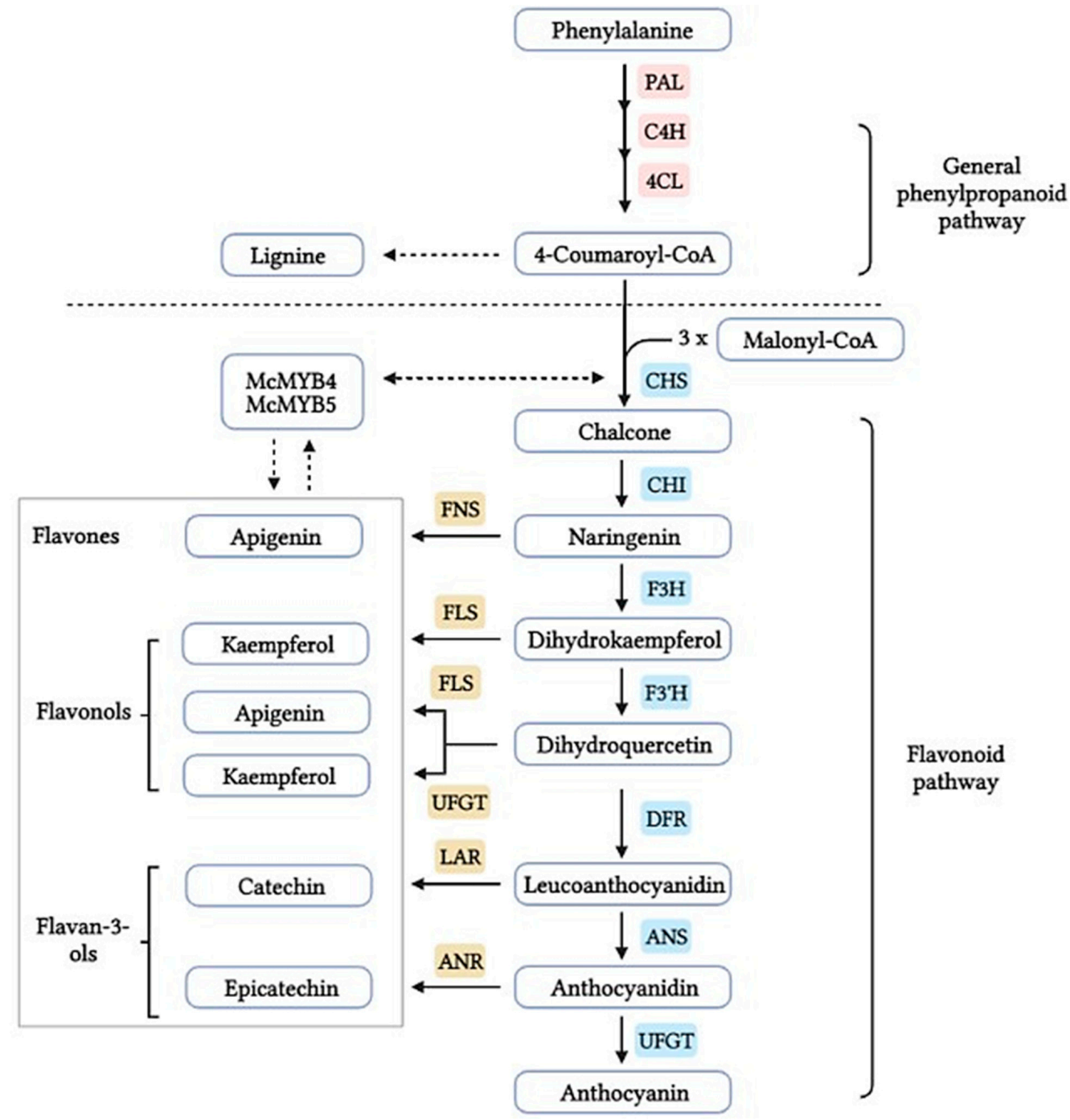

Figure 1. Plant flavonoids biosynthetic pathway [15]. Enzymes for each step are indicated as follows: $\mathrm{PAL}$, phenylalanine ammonia-lyase; $\mathrm{C} 4 \mathrm{H}$, cinnamate 4-hydroxylase; 4CL, 4-coumarate-CoA ligase; $\mathrm{CHS}$, chalcone synthase; $\mathrm{CHI}$, chalcone isomerase; $\mathrm{F} 3 \mathrm{H}$, flavanone 3-hydroxylase; $\mathrm{F}^{\prime} \mathrm{H}$, flavonoid 3'-hydroxylase; DFR, dihydro-flavonol 4-reductase; FNS, flavonol synthase; FLS, flavonol synthase; LAR, leucoanthocyanidin reductase; ANS, anthocyanidin synthase; UFGT, UDP-glucose: flavonoid-3O-glycosyltransferase. 
(2S)-Flavanones are converted stereospecifically to the respective $(2 R, 3 R)$ dihydroflavonols (DHFs) by flavanone 3-hydroxylase (F3H:EC 1.14.11.9) in this case to dihydrokaempferol, then converted by the enzyme flavonoid $3^{\prime}$-hydroxylase (F3' $\mathrm{H}: \mathrm{EC}$ 1.14.14.82) to dihydroquercetin. In Citrus species, the two dihydroflavanols are then converted into flavonols under the action of flavonols synthetase (FLS:EC 1.14.20.6). UDPglucose flavanone-7-O-glucosyltransferase (UFGT:EC 2.4.1.115) and UDP-rhamnose flavanone glucoside rhamnosyltransferase (UFGRT) catalyze the conversion of the flavanone aglycones into their glucosides and rhamnoglucosides [16]. Dihydroflavonol-4-reductase (DFR:EC 1.1.1.219) is a key enzyme required for both anthocyanin biosynthesis and proanthocyanidin accumulation and is involved in the conversion of dihydroflavonols to leucoanthocyanidins [17].

Flavan-3-ols, such as catechin and epicatechin, are synthetized from leucoanthocyanidin and anthocyanidin. Leucoanthocyanidin can be converted to flavan-3-ol (for example, catechin) by leucoanthocyanidin reductase (LAR:EC 1.17.1.3) or to anthocyanidin by anthocyanidin synthase (ANS:EC 1.14.20.4). Anthocyanidin as well can be converted to flavan-3-ol (for example, epicatechin) by anthocyanidin reductase (ANR:EC 1.3.1.77), or glycosylated to form anthocyanin [18].

\section{Flavonoid Composition in Different Parts of Citrus Fruits}

It has been found that Citrus flavonoids are present in almost all the parts of Citrus fruits in different species. Several studies showed that peels are the main sources of polyphenols in Citrus fruits [19]. Seed and peel extracts from numerous Citrus species have proved to be an important source of flavonoids, such as polymethoxyflavones (PMFs), flavanones, and glycosylated flavanones [20]. More than 5000 flavonoid molecules have been identified [21]. Citrus juice is also a major source of flavanone glycosides. Moreover, the contents and types of flavonoids vary among different Citrus species and fruit parts [21]. Flavanones are the most important flavonoids in Citrus species. Hesperedin and naringenin are the predominant flavanones in Citrus fruits [16]. They can be found in all plant parts: stem, branches, bark, flowers, leaves, roots, rhizomes, seeds, fruits, peels, etc. Flavones are the second major group of flavonoids in Citrus, with flavonols in third place because their content is much lower than the other flavonoids $[17,18]$. The content of these components depends upon the age of the plant; most Citrus species accumulate substantial quantities of flavonoids during organ development. Another study showed that flavonoids content might be affected by the maturity of the fruit, the post-harvesting treatments and the extracting processes [22]. Juice preparation and the processing of fresh Citrus fruits may decrease flavonoids content by $50 \%$ due to their water washing methods [23,24], or by elimination of the richest parts of the fruit [25].

In this review, we gather some relevant data for the most abundant flavonoid component in sweet orange $(C$. sinensis), sour orange $(C$. aurantium $)$, mandarin orange $(C$. reticulata), clementine (C. Clementina), lemon (C. limon), and grapefruit (C. Pardisi) juices and peel. It should be noted that Citrus peel exhibit higher contents of flavanones than other parts of the fruit [11]. Depending on their varieties, grapefruit and sour orange are very rich in naringin. Other Citrus species such as sweet orange, and lemon have low quantities of naringin (Table 3). Pupin et al. [26] studied the composition of flavanone glycosides in various orange juice varieties and concluded that narirutin and hesperidin are the most abundant compounds. Hesperidin is present in high levels in clementine, sweet orange, mandarin orange and lemon (39.9-20.5 mg/100 mL juice), while naringin $(23 \mathrm{mg} / 100 \mathrm{~mL}$ juice $)$ and narirutin $(7.6 \mathrm{mg} / 100 \mathrm{~mL}$ juice), glycosides of naringenin, are especially more abundant in grapefruit (Table 3) [27]. In lemon, eriocitrin is present in high level (16.17 mg/100 mL juice) [26]. Didymin is a typical flavonoid glycoside also known as neoponcirin used in Asian countries as a dietary antioxidant [28]. This flavonoid is mainly present in orange, mandarin and grapefruit $(1.89-0.30 \mathrm{mg} / 100 \mathrm{~mL}$ juice) (Table 3).

The most abundant flavanones in Citrus peel are naringin andhesperidin. These flavanones are all glycosylated either by rutinose (6-O- $\alpha$-L-rhamnosyl-D-glucose) or by 
neohesperidose (2-O- $\alpha$-L-rhamnosyl-D-glucose) linked in position 7 [28]. Hesperidin (0.002 to $9.42 \mathrm{mg} / \mathrm{g}$ peel dry basis) $[29,30]$ is the main flavanone in all lemon cultivars while levels of diosmin and eriocitrin are the lowest [31]. Mandarin peel is rich in hesperidin (3.95 to $80.90 \mathrm{mg} / \mathrm{g}$ peel dry basis) [32,33], narirutin (7.66 to $15.3 \mathrm{mg} / \mathrm{g}$ peel dry basis) [22,34], and naringin ( 0.54 to $0.65 \mathrm{mg} / \mathrm{g}$ peel dry basis) [32,33]. Naringin is the most abundant flavonoid in grapefruit and bitter orange peel, conferring a characteristic bitter taste (10.26 to $14.40 \mathrm{mg} / \mathrm{g}$ peel dry basis) [29,35].

Citrus peels contain also polymethoxyl flavones, such as sinensetin $(0.08$ to $0.29 \mathrm{mg} / \mathrm{g}$ dry bassis), nobiletin ( 0.2 to $14.05 \mathrm{mg} / \mathrm{g}$ dry basis), tangeretin (0.16 to $7.99 \mathrm{mg} / \mathrm{g}$ dry basis) and heptamethoxyflavone [26,36-38]. The glycosylated flavones are present in small quantities in Citrus peel, such as diosmin, rhoifoline, isorhoifoline, luteolin. Other flavonoids are present in very small quantities in citrus peel, such as flavonols (quercetin, rutin, myricetin, and kaempferol) [39].

Several studies have shown that the extracts of seeds and leaves of Citrus contain high quantities of phenolic compounds, such as flavonoids [40,41]. Naringin is the most abundant flavonoid in grapefruit seeds $(0.2 \mathrm{mg} / \mathrm{g}$ seeds) [41]. The flavonoid content in Citrus peel is much higher than in the seeds. They appear in plants and foods mostly as glycosides [42].

Table 3. Flavonoid composition of some Citrus juices $[4,43,44]$.

\begin{tabular}{|c|c|c|c|c|c|c|c|c|c|c|}
\hline & \multicolumn{5}{|c|}{ Flavanones } & \multicolumn{4}{|c|}{ Flavones } & \multirow[b]{2}{*}{$\begin{array}{c}\text { Total } \\
\text { Flavonoids } \\
\text { Content }\end{array}$} \\
\hline & Hesperidin & Narirutin & Naringin & Didymin & Eriocitrin & Diosmin & $\begin{array}{c}\text { 6,8-di-C- } \\
\text { Glu- } \\
\text { Diosmetin }\end{array}$ & $\begin{array}{c}\text { 6,8-di-C- } \\
\text { Glu- } \\
\text { Apigenin }\end{array}$ & Sinensitin & \\
\hline Orange & 28.6 & 5.2 & - & 1.89 & 0.31 & 0.09 & 0.35 & 5.72 & 0.37 & 18.34 \\
\hline $\begin{array}{c}\text { Sour } \\
\text { orange }\end{array}$ & - & - & 1.97 & - & - & 0.15 & - & - & - & - \\
\hline $\begin{array}{l}\text { Mandarin } \\
\text { orange }\end{array}$ & 24.3 & 3.92 & - & 1.44 & 0.31 & - & - & - & 1.05 & - \\
\hline Clementine & 39.9 & 4.64 & 0.08 & - & - & 1.25 & 0.2 & 0.5 & - & 19.23 \\
\hline Lemon & 20.5 & - & - & - & 16.17 & 3.12 & 4.95 & 1.17 & - & - \\
\hline Grapefruit & 0.93 & 7.60 & 23.0 & 0.3 & 0.41 & - & - & - & - & - \\
\hline
\end{tabular}

Mean values are expressed in $\mathrm{mg} / 100 \mathrm{~mL}$ of juice.

\section{Citrus Flavonoid Extraction Techniques}

Citrus flavonoids were discovered to be omnipresent in practically all portions of Citrus fruits from various species [45]. Extraction is a crucial stage in the analytical process, and its success has a significant impact on the quality of the final results [46]. Flavonoids can only be isolated, detected, and characterized after using the appropriate extraction procedure. Generally, to extract bioactive compounds, several processes can be used, many of which have largely remained constant for hundreds of years. All of these strategies share the same goals: (a) extracting selected bioactive chemicals from complicated plant samples; (b) improving analytical method selectivity and avoiding the presence of interferents that could alter the analysis; and (c) improving bioassay sensitivity by increasing the concentration of targeted compounds before analysis [46-48].

\subsection{Conventional Extraction Techniques}

Various traditional extraction procedures can be used to extract bioactive chemicals from plant sources. The recovery of bioactive chemicals from plant matrices, using common solvents, is referred to as conventional extraction (with or without heat treatment) [49]. The majority of these approaches rely on the extraction power of the various solvents in use, as well as the use of heat and/or mixing. The known conventional procedures for extracting bioactive chemicals from plants are (1) maceration, (2) infusion, (3) decoction, (4) hot continuous extraction (Soxhlet extraction), (5) hydrodistillation, and (6) percolation. 


\subsection{Non-Conventional Extraction Techniques}

Degradation of targeted compounds due to high temperatures and long extraction times in solvents is a major problem encountered in classic extraction techniques. On this basis, finding various extraction strategies to overcome this difficulty becomes a critical step to improve extraction efficiency and/or selectivity. Or, using dedicated aids/energy-intensive intrants, such as microwave-assisted extraction [50], pressurized liquid extraction [51], supercritical fluid extraction [52], ultrasound-assisted extraction, cold plasma-assisted extraction [53], high pressure assisted extraction [54], pulsed electric field assisted extraction [55], and enzyme-assisted extraction [56], is well documented in the scientific literature as an efficient alternative. In general, while studying plant-derived chemicals, the method and solvents utilized for extraction must be carefully adopted [57]. In this context, some of the non-conventional extraction methods are discussed.

\subsubsection{Ultrasound Assisted Extraction (UAE)}

Ultrasound-assisted extraction is a new technology that is being used to extract natural products that previously took many hours to extract using traditional methods. Initially, it was employed to preserve food, but in the last decade, it has also been utilized to extract beneficial substances (mainly polyphenols). Because of the simplicity of the method, benefits such as reduced extraction time, increased extract yield, and the use of water as a solvent, which reduces the usage of organic solvents, are documented. Therefore, to avoid unwanted reactions generated by the UAE and maximize the extraction yield, the extraction parameters (e.g., extraction duration, solvent system, and, if possible, U.S. frequency) should be tuned prior to developing the extraction process [58]. LondoñoLondoño et al. 2010, conducted the extraction of Citrus peel flavonoids from C. sinensis, C. latifolia, and C. reticulata under optimal ultrasonic conditions of $60 \mathrm{kHz}, 40^{\circ} \mathrm{C}$, for $1 \mathrm{~h}$, using methanol as a solvent [59].

\subsubsection{Supercritical Fluid Extraction (SFE)}

Supercritical extraction is a modern technique that uses gases that have exceeded their critical pressure and temperature, resulting in a fluid with qualities in between a gas and a liquid [60]. Supercritical $\mathrm{CO}_{2}$ extraction (using $\mathrm{CO}_{2}$ as a solvent, mainly due to its adaptability, availability, and low cost), is a preferred approach for extracting numerous active compounds. Despite the fact that any gas can be employed as a supercritical fluid [61] because flavonoids are polar molecules, SFE requires the presence of a cosolvent, such as ethanol or methanol [62]. A study was carried out to extract nobiletin and tangeritin from C. depressa var Hayata. The authors tested both methanol and ethanol as solvents. Under the conditions reported in their paper, Lee et al. [36] found that SFE provides a higher amount of flavonoids $(+7 \%)$ than UAE.

\section{Citrus Flavonoids and Chronic Diseases}

Over the last few decades, several epidemiological studies have shown the effect of a high dietary intake of phenolic compounds, such as flavonoids, on lethal diseases, particularly their role in the prevention of cardiovascular disease and cancer. The mechanism of action involved in the health effects of flavonoids is mainly done by the inhibition of lipid and DNA oxidation (antioxidant activity) and gene expression control $[63,64]$. The health effects of flavonoids include the following.

\subsection{Antioxidant Action}

Flavonoids are capable of scavenging oxygen free radicals by the transfer of an electron or hydrogen. The unpaired electron can be delocalized over the entire aromatic cycle. However, it can continue to evolve according to several processes, either by reacting with radicals or other antioxidants, or with biomolecules. The antiradical activity of phenols has been correlated with the potential for oxidation of flavonoids [65]. The antioxidant activity of flavonoids can be exerted by the complexation of transition metals. Indeed, 
these accelerate the formation of reactive oxygen species. In addition, the complexation of flavonoids by transition metals can improve their antioxidant capacity by decreasing their oxidation potential $[65,66]$. Flavonoids are known by their ability to inhibit several enzymes, including, in particular, the oxido-reductases, which involve, during their catalytic cycle, radical species (such as lipoxygenase, cyclooxygenase, monoxygenase, xanthine oxidase, phospholipase A2, and protein kinase) [65]. Due to their antioxidant capacity, flavonoids are used in several fields. Several studies propose the replacement of synthetic antioxidants, such as butylhydroxyansol and butylhydroxytoluene, with natural antioxidants because of their toxicity involved in promoting the development of cancer cells [67].

\subsection{Anti-Carcinogenic Activity}

Citrus flavonoids (flavanones and polymethoxylated flavones) were found to have interesting properties for the pharmaceutical field. These compounds, due to their properties, help prevent certain diseases, such as cancers [68]. In recent years, many studies have shown that there is a connection between flavonoid intake and their potential therapeutic application against cancer. Jagetia et al. [69] showed that flavonoids have an anti-mutagenic effect by protecting DNA from oxidative damage and neutralize free radicals, which cause mutations. Other studies showed that flavonoids might be implicated on anti-proliferative mechanisms [42]. Studies on mice showed that hesperetin intake promoted the inhibition of proliferating cell nuclear antigen and growth inhibition of aromatase-expressing MCF-7 tumor in ovariectomized athymic mice [70,71]. Hesperidin, as the glycoside of hesperetin, led to cell apoptosis via conducting the expression of p53 and peroxisome proliferatoractivated receptor gamma [72]. In a recent study, naringenin showed anti-mutagenic modification by activating DNA repair, following oxidative damage in human prostate cancer cells [73]. Current research indicates that didymin, a typical dietary glycoside flavonoid also known as neoponcirin, demonstrated an anti-proliferative effect on breast cancer [74]. Moreover, tangeretin and nobiletin can exhibit anti-angiogenesis activity by the inhibition of angiogenic differentiation and exertion of cell cycle arrest in breast and human colon cancer cell lines [75,76]. In summary, several studies showed that flavonoids might exert an anti-carcinogenesis effect by blocking the metastasis cascade, the inhibition of cancer cell mobility in circulatory systems, proapoptosis, blocking cell cycle progression and antiangiogenesis [19].

\subsection{Cardiovascular Effects}

Cardiovascular disease is a general term for conditions affecting the heart and blood circulation, including coronary artery diseases, such as angina and myocardial infarction. This may be caused by high blood pressure, diabetes, obesity, high blood cholesterol ... etc. Diabetes leads to increased inflammation, and oxidative stress also deteriorates endothelial cell dysfunction. Flavonoid-rich foods such as Citrus fruit can promote cardioprotector effects mainly derived from their antioxidant and anti-inflammatory activities [77]. Hesperidin exerts an anti-obesity activity and hypoglycemic activity by regulating glucose metabolism [78]. Didymin inhibits the release of various inflammatory cytokines and chemokines from high glucose-treated human umbilical vein endothelial cells [79]. Studies on mice showed potential vasorelaxant effects of hesperetin, hesperidin, naringenin and naringin by the inhibition of different phosphodiesterase isoenzymes [80,81]. Another effect of flavonoids on the vascular system is the inhibition of platelet aggregation and reducing clot formation [63]. In another study on mice fed with a cholesterol-rich diet, naringenin showed a reduction in plasma cholesterol and hepatic triacylglycerols concentrations [82].

\subsection{Anti-Microbial Effects}

Extensive research was conducted on the effect of flavonoids on microbial development. According to Kaul et al. [83], hesperidin has antiviral activity against a variety of viruses (i.e., parainfluenza, polio, and herpes). According to a recent study by Vikram et al. (2011) [84], it was demonstrated that naringenin has an antimicrobial effect on Salmonella 
typhimurium by attenuation of virulence and cell motility [84]. Another study showed that naringenin, kaempferol, quercetin and apigenin could affect the antagonists of cell-cell signaling and inhibit E. coli biofilm formation. Moreover, naringenin can reduce the expression of genes encoding type secretion system in Vibrio harveyi [85]. Shetty et al. suggested that flavonoids extracted from $C$. sinensis and C. limon peel have antimicrobial activity against dental caries bacteria Streptococcus mutans and Lactobacillus acidophilus [86].

\subsection{Other Biological Effects}

In addition to biological effects mentioned above, several bioactivities of Citrus fruits from latest research were also reviewed. Citrus flavonoids exhibit several anti-aging activities. In vitro study showed that flavonoids extracted from C. reticulata has strong anti-collagenase and anti-elastase potential [87]. In Morocco, according to Bencheikh et al., Citrus species (lemon, lime, age-leaved rock-rose and sweet orange) are widely used in the treatment of renal problems, including renal stones, colic and insufficiency [88]. Murata et al. showed both hesperetin and naringenin extracted from Citrus fruits had anti-allergic effects on rat basophil leukemia RBL-2H3 cells. The in vivo and in vitro results suggest that these molecules can attenuate the symptoms of allergy by inhibiting phosphorylation of protein kinase B (Akt) and the inhibition of degranulation by suppression of the pathway signals [89]. There are also many studies of an animal model describing the positive effects of flavonoids on the nervous system. A study by Kawahata et al. [90] suggests that nobiletin extracted from $C$. depressa can enhance learning and memory. Moreover, a study showed that there is a connection between hesperetin and naringenin intake and a lower incidence of cerebrovascular disease and asthma [91].

\section{Industrial Application of Citrus Flavonoids}

Flavonoids extracted from Citrus fruits are already used as natural antioxidants in the following:

- Pharmaceutical and nutraceutical supplements:

Flavanones and polymethoxylated flavones extracted from Citrus fruits are mainly used as natural antioxidants in the formulation of pharmaceutical products. They are used in many vitamin complexes and as the active ingredient of certain drugs (circulatory system disease) $[6,90,91]$. Citrus byproduct processing could be a significant source of flavonoids due to the large volume of peel produced, in addition to being a source of D-limonene-rich essential oil. Fruit residues from C. aurantium, which are typically discarded as waste, could be used to make valuable nutraceuticals [92].

- $\quad$ Agri-food industry:

In the food industry, naringin is used to flavor beverages, sweets and baked goods, because of its typical bitter taste [35]. Moreover, due to their antioxidant activity, hesperidin and narirutin have protective effects against the peroxidation of lipids either in sunflower oil stored for 24 days at high temperature or in biscuits [33]. Citrus peel was also used to produce hesperidin and neohesperidin for the synthesis of dihydrochalcones. These compounds are used in the food industry as sweeteners and flavor enhancers [93]. In addition, anthocyanins derived from flavonols are used as coloring agents (E163) in confectionery, dairy products and desserts or to compensate for fruit discoloration induced by certain processing steps [94].

- Other industrial applications as a corrosion inhibitor:

Several studies were conducted on the effect of flavonoids on carbon steel and copper [94,95]. M'hiri et al. 2017 [95] investigated the inhibition of carbon steel corrosion by neohesperidin and naringin in the presence of hydrochloric acid. In the paper of Al-Qudah, some flavonoid compounds, such as apigenin, luteolin and quercetin, were used to study the corrosion behavior of copper in nitric acid [96]. The authors reported that the inhibition of copper corrosion increases as the concentration of flavonoids increases. 


\section{Conclusions}

Even though our review concentrated on flavonoids in Citrus species, their biosynthesis, classification, and therapeutic activities, conventional and non-conventional techniques were also discussed throughout this review. Citrus species are regarded as being among the most economically important biological resources since they contain a diverse range of phytonutrients and phytochemicals with promising therapeutic properties. Thus far, the generation of pharmaceuticals containing flavonoids derived from Citrus species is still challenging, mostly related to the identification, extraction, and purification of these compounds. Additionally, to fully understand the effects of Citrus flavonoids, more research (primarily randomized controlled clinical trials) is needed.

Author Contributions: Conceptualization M.A. (Mohamed Addi) and C.H., methodology A.E. (Amine Elbouzidi), M.A. (Malika Abid) and D.T., validation A.E. (Ahmed Elamrani), M.A. (Malika Abid) and C.H., formal analysis A.E. (Ahmed Elamrani), D.T., writing-original draft preparation M.A. (Mohamed Addi) review and editing, M.A. (Mohamed Addi), C.H. supervision, C.H. all the authors. All authors have read and agreed to the published version of the manuscript.

Funding: This research was funded by the Conseil Départemental d'Eure et Loir and the Région Centre-Val de Loire (InnoCosm, 20037UNI0000CLB).

Institutional Review Board Statement: Not applicable.

Informed Consent Statement: Not applicable.

Data Availability Statement: All the data supporting the findings of this study are included in this article.

Acknowledgments: C.H. and D.T. acknowledge the research fellowship of Le Studium-Institute for Advanced Studies, Loire Valley, Orleans, France. C.H. and D.T. gratefully acknowledge the support of French government via the French Embassy in Thailand in the form of the Junior Research Fellowship Program. C.H. and D.T. gratefully acknowledge the support of Campus France through the PHC SIAM (PNPIA, Project 44926WK).

Conflicts of Interest: The authors declare no conflict of interest.

\section{References}

1. Zhou, Z.Q. Citrus Fruits Nutrition; Science Press: Beijing, China, 2012.

2. González-Molina, E.; Domínguez-Perles, R.; Moreno, D.A.; García-Viguera, C. Natural bioactive compounds of Citrus limon for food and health. J. Pharm. Biomed. Anal. 2010, 51, 327-345. [CrossRef]

3. Awad, M.A.; de Jager, A.; van der Plas, L.H.W.; van der Krol, A.R. Flavonoid and chlorogenic acid changes in skin of 'Elstar' and 'Jonagold'apples during development and ripening. Sci. Hortic. 2001, 90, 69-83. [CrossRef]

4. Peterson, J.J.; Dwyer, J.T.; Beecher, G.R.; Bhagwat, S.A.; Gebhardt, S.E.; Haytowitz, D.B.; Holden, J.M. Flavanones in oranges, tangerines (mandarins), tangors, and tangelos: A compilation and review of the data from the analytical literature. J. Food Compos. Anal. 2006, 19, S66-S73. [CrossRef]

5. Li, B.B.; Smith, B.; Hossain, M.M. Extraction of phenolics from citrus peels: I. Solvent extraction method. Sep. Purif. Technol. 2006, 48, 182-188. [CrossRef]

6. Benavente-Garcia, O.; Castillo, J. Update on uses and properties of citrus flavonoids: New findings in anticancer, cardiovascular, and anti-inflammatory activity. J. Agric. Food Chem. 2008, 56, 6185-6205. [CrossRef]

7. Zou, Z.; Xi, W.; Hu, Y.; Nie, C.; Zhou, Z. Antioxidant activity of Citrus fruits. Food Chem. 2016, 196, 885-896. [CrossRef] [PubMed]

8. Reuther, W.; Batchelor, L.D.; Webber, H.J. History, World Distribution, Botany, and Varieties; University of California, Division of Agricultural Sciences: Berkeley, CA, USA, 1967.

9. Swingle, W.T. The Botany of Citrus and Its Wild Relatives. In The Citrus Industry; Webber, H.J., Batchelor, L.D., Reuther, W., Eds.; University of California: Berkeley, CA, USA, 1967; Volume 1, pp. 190-430.

10. Tanaka, T. Fundamental discussion of Citrus classification. Stud. Citrol. 1977, 14, 1-6.

11. Krueger, R.R.; Navarro, L. Citrus Germplasm Resources. In Citrus Genetics, Breeding and Biotechnology; CAB International: Wallingford, UK, 2007. [CrossRef]

12. Ververidis, F.; Trantas, E.; Douglas, C.; Vollmer, G.; Kretzschmar, G.; Panopoulos, N. Biotechnology of flavonoids and other phenylpropanoid-derived natural products. Part I: Chemical diversity, impacts on plant biology and human health. Biotechnol. J. 2007, 2, 1214-1234. [CrossRef]

13. Vogt, T. Phenylpropanoid Biosynthesis. Mol. Plant. 2010, 3, 2-20. [CrossRef] 
14. Austin, M.B.; Noel, J.P. The chalcone synthase superfamily of type III polyketide synthases. Nat. Prod. Rep. 2003, 20, 79-110. [CrossRef]

15. Tai, D.; Tian, J.; Zhang, J.; Song, T.; Yao, Y. A Malus crabapple chalcone synthase gene, McCHS, regulates red petal color and flavonoid biosynthesis. PLoS ONE. 2014, 9, e110570. [CrossRef]

16. Lewinsohn, E.; Britsch, L.; Mazur, Y.; Gressel, J. Flavanone glycoside biosynthesis in citrus: Chalcone synthase, UDP-glucose: Flavanone-7-O-glucosyl-transferase and-rhamnosyl-transferase activities in cell-free extracts. Plant Physiol. 1989, 91, 1323-1328. [CrossRef] [PubMed]

17. Li, Y.; Liu, X.; Cai, X.; Shan, X.; Gao, R.; Yang, S.; Han, T.; Wang, S.; Wang, L.; Gao, X. Dihydroflavonol 4-Reductase Genes from Freesia hybrida Play Important and Partially Overlapping Roles in the Biosynthesis of Flavonoids. Front. Plant Sci. 2017, 8 , 428. [CrossRef] [PubMed]

18. Liu, C.; Wang, X.; Shulaev, V.; Dixon, R.A. A role for leucoanthocyanidin reductase in the extension of proanthocyanidins. Nat. Plants. 2016, 2, 1-7. [CrossRef] [PubMed]

19. Wang, L.; Wang, J.; Fang, L.; Zheng, Z.; Zhi, D.; Wang, S.; Li, S.; Ho, C.-T.; Zhao, H. Anticancer activities of citrus peel polymethoxyflavones related to angiogenesis and others. BioMed Res. Int. 2014, 2014, 453972. [CrossRef] [PubMed]

20. Xi, W.; Zhang, Y.; Sun, Y.; Shen, Y.; Ye, X.; Zhou, Z. Phenolic composition of Chinese wild mandarin (Citrus reticulata Balnco.) pulps and their antioxidant properties. Ind. Crops Prod. 2014, 52, 466-474. [CrossRef]

21. Harborne, J.B. The Flavonoids: Advances in Research Since 1980; Springer: Berlin/Heidelberg, Germany, 2013.

22. Xu, G.; Ye, X.; Liu, D.; Ma, Y.; Chen, J. Composition and distribution of phenolic acids in Ponkan (Citrus poonensis Hort. ex Tanaka) and Huyou (Citrus paradisi Macf. Changshanhuyou) during maturity. J. Food Compos. Anal. 2008, 21, 382-389. [CrossRef]

23. Sánchez-Moreno, C.; Plaza, L.; Elez-Martínez, P.; De Ancos, B.; Martín-Belloso, O.; Cano, M.P. Impact of high pressure and pulsed electric fields on bioactive compounds and antioxidant activity of orange juice in comparison with traditional thermal processing. J. Agric. Food Chem. 2005, 53, 4403-4409. [CrossRef]

24. Polydera, A.C.; Stoforos, N.G.; Taoukis, P.S. Effect of high hydrostatic pressure treatment on post processing antioxidant activity of fresh Navel orange juice. Food Chem. 2005, 91, 495-503. [CrossRef]

25. Del Caro, A.; Piga, A.; Vacca, V.; Agabbio, M. Changes of flavonoids, vitamin C and antioxidant capacity in minimally processed citrus segments and juices during storage. Food Chem. 2004, 84, 99-105. [CrossRef]

26. Pupin, A.M.; Dennis, M.J.; Toledo, M.C.F. Flavanone glycosides in Brazilian orange juice. Food Chem. 1998, 61, 275-280. [CrossRef]

27. Tomás-Barberán, F.A.; Clifford, M.N. Dietary hydroxybenzoic acid derivatives-nature, occurrence and dietary burden. J. Sci. Food Agric. 2000, 80, 1024-1032. [CrossRef]

28. Yao, Q.; Lin, M.-T.; Zhu, Y.-D.; Xu, H.-L.; Zhao, Y.-Z. Recent trends in potential therapeutic applications of the dietary flavonoid didymin. Molecules 2018, 23, 2547. [CrossRef] [PubMed]

29. Wang, Y.-C.; Chuang, Y.-C.; Hsu, H.-W. The flavonoid, carotenoid and pectin content in peels of citrus cultivated in Taiwan. Food Chem. 2008, 106, 277-284. [CrossRef]

30. Russo, M.; Bonaccorsi, I.; Torre, G.; Sarò, M.; Dugo, P.; Mondello, L. Underestimated sources of flavonoids, limonoids and dietary fibre: Availability in lemon's by-products. J. Funct. Foods. 2014, 9, 18-26. [CrossRef]

31. Del Río, J.A.; Fuster, M.D.; Gómez, P.; Porras, I.; Garcia-Lidón, A.; Ortuño, A. Citrus limon: A source of flavonoids of pharmaceutical interest. Food Chem. 2004, 84, 457-461. [CrossRef]

32. Hayat, K.; Hussain, S.; Abbas, S.; Farooq, U.; Ding, B.; Xia, S.; Jia, C.; Zhang, X.; Xia, W. Optimized microwave-assisted extraction of phenolic acids from citrus mandarin peels and evaluation of antioxidant activity in vitro. Sep. Purif. Technol. 2009, 70, 63-70. [CrossRef]

33. Tumbas, V.T.; Ćetković, G.S.; Đilas, S.M.; Čanadanović-Brunet, J.M.; Vulić, J.J.; Knez, Ž.; Škerget, M. Antioxidant activity of mandarin (Citrus reticulata) peel. Acta Period. Technol. 2010, 195-203. [CrossRef]

34. Cheigh, C.-I.; Chung, E.-Y.; Chung, M.-S. Enhanced extraction of flavanones hesperidin and narirutin from Citrus unshiu peel using subcritical water. J. Food Eng. 2012, 110, 472-477. [CrossRef]

35. Giannuzzo, A.N.; Boggetti, H.J.; Nazareno, M.A.; Mishima, H.T. Supercritical fluid extraction of naringin from the peel of Citrus paradisi. Phytochem. Anal. 2003, 14, 221-223. [CrossRef]

36. Lee, Y.-H.; Charles, A.L.; Kung, H.-F.; Ho, C.-T.; Huang, T.-C. Extraction of nobiletin and tangeretin from Citrus depressa Hayata by supercritical carbon dioxide with ethanol as modifier. Ind. Crops Prod. 2010, 31, 59-64. [CrossRef]

37. Li, W.; Wang, Z.; Wang, Y.; Jiang, C.; Liu, Q.; Sun, Y.; Zheng, Y. Pressurised liquid extraction combining LC-DAD-ESI/MS analysis as an alternative method to extract three major flavones in Citrus reticulata 'Chachi' (Guangchenpi). Food Chem. 2012, 130, 1044-1049. [CrossRef]

38. Toledo-Guillén, A.R.; Higuera-Ciapara, I.; García-Navarrete, G.; De la Fuente, J.C. Extraction of Bioactive Flavonoid Compounds from Orange (Cit-rus sinensis) Peel Using Supercritical $\mathrm{CO}_{2}$. Atherosclerosis 2010, 178, 25-32.

39. Zhang, J. Flavonoids in Grapefruit and commercial grapefruit juices: Concentration, distribution, and potential health benefi ts. Proc. Proc. Fla. State Hortic. Soc. 2007, 120, 288-294.

40. Al-Anbari, A.K.H.; Hasan, M.A. Antioxidant activity in some citrus leaves and seeds ethanolic extracts. In Proceedings of the International Conference on Advances in Agricultural, Biological and Environmental Sciences (AABES), London, UK, 22-23 July 2015; pp. 22-23. 
41. Yu, J.; Dandekar, D.V.; Toledo, R.T.; Singh, R.K.; Patil, B.S. Supercritical fluid extraction of limonoids and naringin from grapefruit (Citrus paradisi Macf.) seeds. Food Chem. 2007, 105, 1026-1031. [CrossRef]

42. Tripoli, E.; La Guardia, M.; Giammanco, S.; Di Majo, D.; Giammanco, M. Citrus flavonoids: Molecular structure, biological activity and nutritional properties: A review. Food Chem. 2007, 104, 466-479. [CrossRef]

43. Peterson, J.J.; Beecher, G.R.; Bhagwat, S.A.; Dwyer, J.T.; Gebhardt, S.E.; Haytowitz, D.B.; Holden, J.M. Flavanones in grapefruit, lemons, and limes: A compilation and review of the data from the analytical literature. J. Food Compos. Anal. 2006, 19, S74-S80. [CrossRef]

44. Rao, M.J.; Wu, S.; Duan, M.; Wang, L. Antioxidant Metabolites in Primitive, Wild, and Cultivated Citrus and Their Role in Stress Tolerance. Molecules 2021, 26, 5801. [CrossRef]

45. Wang, S.; Yang, C.; Tu, H.; Zhou, J.; Liu, X.; Cheng, Y.; Luo, J.; Deng, X.; Zhang, H.; Xu, J. Characterization and Metabolic Diversity of Flavonoids in Citrus Species. Sci. Rep. 2017, 7, 10549. [CrossRef]

46. Ledesma-Escobar, C.A.; de Castro, M.D.L. Towards a comprehensive exploitation of citrus. Trends Food Sci. Technol. 2014, 39, 63-75. [CrossRef]

47. Smith, R.M. Before the injection—modern methods of sample preparation for separation techniques. J. Chromatogr. A 2003, 1000, 3-27. [CrossRef]

48. Azmir, J.; Zaidul, I.S.M.; Rahman, M.M.; Sharif, K.M.; Mohamed, A.; Sahena, F.; Jahurul, M.H.A.; Ghafoor, K.; Norulaini, N.A.N.; Omar, A.K.M. Techniques for extraction of bioactive compounds from plant materials: A review. J. Food Eng. 2013, 117, 426-436. [CrossRef]

49. Barba, F.J.; Putnik, P.; Bursać Kovačević, D.; Poojary, M.M.; Roohinejad, S.; Lorenzo, J.M.; Koubaa, M. Impact of conventional and non-conventional processing on prickly pear (Opuntia spp.) and their derived products: From preservation of beverages to valorization of by-products. Trends Food Sci. Technol. 2017, 67, 260-270. [CrossRef]

50. Pina-Pérez, M.C.; Rivas, A.; Martínez, A.; Rodrigo, D. Effect of thermal treatment, microwave, and pulsed electric field processing on the antimicrobial potential of açaí (Euterpe oleracea), stevia (Stevia rebaudiana Bertoni), and ginseng (Panax quinquefolius L.) extracts. Food Control. 2018, 90, 98-104. [CrossRef]

51. Ciulu, M.; Quirantes-Piné, R.; Spano, N.; Sanna, G.; Borrás-Linares, I.; Segura-Carretero, A. Evaluation of new extraction approaches to obtain phenolic compound-rich extracts from Stevia rebaudiana Bertoni leaves. Ind. Crops Prod. 2017, 108, 106-112. [CrossRef]

52. Uwineza, P.A.; Gramza-Michałowska, A.; Bryła, M.; Waśkiewicz, A. Antioxidant Activity and Bioactive Compounds of Lamium album Flower Extracts Obtained by Supercritical Fluid Extraction. Appl. Sci. 2021, 11, 7419. [CrossRef]

53. Kujundžić, D.; Jambrak, A.R.; Vukušić, T.; Stulić, V.; Kljusurić, J.G.; Banović, M.; Herceg, Z. Near-infrared spectroscopic characterization of steviol glycosides extracted from Stevia rebaudiana Bertoni using high-power ultrasound and gas-phase plasma. J. Food Nutr. Res. 2017, 56, 109-120.

54. Barba, F.J.; Terefe, N.S.; Buckow, R.; Knorr, D.; Orlien, V. New opportunities and perspectives of high pressure treatment to improve health and safety attributes of foods. A review. Food Res. Int. 2015, 77, 725-742. [CrossRef]

55. Tamborrino, A.; Urbani, S.; Servili, M.; Romaniello, R.; Perone, C.; Leone, A. Pulsed electric fields for the treatment of olive pastes in the oil extraction process. Appl. Sci. 2020, 10, 114. [CrossRef]

56. Zuorro, A.; Lavecchia, R.; González-Delgado, Á.D.; García-Martinez, J.B.; L'Abbate, P. Optimization of enzyme-assisted extraction of flavonoids from corn husks. Processes 2019, 7, 804. [CrossRef]

57. Vongsak, B.; Sithisarn, P.; Mangmool, S.; Thongpraditchote, S.; Wongkrajang, Y.; Gritsanapan, W. Maximizing total phenolics, total flavonoids contents and antioxidant activity of Moringa oleifera leaf extract by the appropriate extraction method. Ind. Crops Prod. 2013, 44, 566-571. [CrossRef]

58. Ledesma-Escobar, C.A.; Priego-Capote, F.; Luque de Castro, M.D. Chapter 9-Relevance and Analysis of Citrus Flavonoids. In Polyphenols in Plants, 2nd ed.; Academic Press: Cambridge, MA, USA, 2019; pp. 133-150. ISBN 978-0-12-813768-0.

59. Londoño-Londoño, J.; de Lima, V.R.; Lara, O.; Gil, A.; Pasa, T.B.C.; Arango, G.J.; Pineda, J.R.R. Clean recovery of antioxidant flavonoids from citrus peel: Optimizing an aqueous ultrasound-assisted extraction method. Food Chem. 2010, 119, 81-87. [CrossRef]

60. McHugh, M.; Krukonis, V. Supercritical Fluid Extraction: Principles and Practice; Elsevier: Amsterdam, The Netherlands, 2013; ISBN 0080518176.

61. Machado, B.A.S.; Pereira, C.G.; Nunes, S.B.; Padilha, F.F.; Umsza-Guez, M.A. Supercritical fluid extraction using $\mathrm{CO}_{2}$ : $\mathrm{Main}$ applications and future perspectives. Sep. Sci. Technol. 2013, 48, 2741-2760. [CrossRef]

62. Díaz-Reinoso, B.; Moure, A.; Domínguez, H.; Parajó, J.C. Supercritical $\mathrm{CO}_{2}$ Extraction and Purification of Compounds with Antioxidant Activity. J. Agric. Food Chem. 2006, 54, 2441-2469. [CrossRef] [PubMed]

63. Kris-Etherton, P.M.; Hecker, K.D.; Bonanome, A.; Coval, S.M.; Binkoski, A.E.; Hilpert, K.F.; Griel, A.E.; Etherton, T.D. Bioactive compounds in foods: Their role in the prevention of cardiovascular disease and cancer. Am. J. Med. 2002, 113, 71-88. [CrossRef]

64. Patil, A.P.; Patil, V.V.; Patil, V.R. In-vitro free radicals scavenging activity of Madhuca indica Gmel. Pharmacologyonline 2009, 2, 1344-1352.

65. Van Acker, S.A.B.E.; Tromp, M.N.J.L.; Griffioen, D.H.; Van Bennekom, W.P.; Van Der Vijgh, W.J.F.; Bast, A. Structural aspects of antioxidant activity of flavonoids. Free Radic. Biol. Med. 1996, 20, 331-342. [CrossRef] 
66. Afanas'eva, I.B.; Ostrakhovitch, E.A.; Mikhal'chik, E.V.; Ibragimova, G.A.; Korkina, L.G. Enhancement of antioxidant and anti-inflammatory activities of bioflavonoid rutin by complexation with transition metals. Biochem. Pharmacol. 2001, 61, 677-684. [CrossRef]

67. Moure, A.; Cruz, J.M.; Franco, D.; Domínguez, J.M.; Sineiro, J.; Domínguez, H.; Núñez, M.J.; Parajó, J.C. Natural antioxidants from residual sources. Food Chem. 2001, 72, 145-171. [CrossRef]

68. Bocco, A.; Cuvelier, M.-E.; Richard, H.; Berset, C. Antioxidant activity and phenolic composition of citrus peel and seed extracts. J. Agric. Food Chem. 1998, 46, 2123-2129. [CrossRef]

69. Jagetia, G.C.; Venkatesha, V.A.; Reddy, T.K. Naringin, a citrus flavonone, protects against radiation-induced chromosome damage in mouse bone marrow. Mutagenesis 2003, 18, 337-343. [CrossRef]

70. Lai, C.-S.; Li, S.; Liu, C.B.; Miyauchi, Y.; Suzawa, M.; Ho, C.-T.; Pan, M.-H. Effective suppression of azoxymethane-induced aberrant crypt foci formation in mice with citrus peel flavonoids. Mol. Nutr. Food Res. 2013, 57, 551-555. [CrossRef] [PubMed]

71. Li, S.; Lin, Y.-C.; Ho, C.-T.; Lin, P.-Y.; Suzawa, M.; Wang, H.-C.; Chu, C.-L.; Chen, D.-Y.; Lin, C.-C. Formulated extract from multiple citrus peels impairs dendritic cell functions and attenuates allergic contact hypersensitivity. Int. Immunopharmacol. 2014, 20, 12-23. [CrossRef] [PubMed]

72. Ghorbani, A.; Nazari, M.; Jeddi-Tehrani, M.; Zand, H. The citrus flavonoid hesperidin induces p53 and inhibits NF- $\kappa B$ activation in order to trigger apoptosis in NALM-6 cells: Involvement of PPAR $\gamma$-dependent mechanism. Eur. J. Nutr. 2012, 51, 39-46. [CrossRef]

73. Gao, K.; Henning, S.M.; Niu, Y.; Youssefian, A.A.; Seeram, N.P.; Xu, A.; Heber, D. The citrus flavonoid naringenin stimulates DNA repair in prostate cancer cells. J. Nutr. Biochem. 2006, 17, 89-95. [CrossRef]

74. Hsu, Y.; Hsieh, C.; Tsai, E.; Hung, J.; Chang, W.; Hou, M.; Kuo, P. Didymin reverses phthalate ester-associated breast cancer aggravation in the breast cancer tumor microenvironment. Oncol. Lett. 2016, 11, 1035-1042. [CrossRef]

75. Alshatwi, A.A.; Ramesh, E.; Periasamy, V.S.; Subash-Babu, P. The apoptotic effect of hesperetin on human cervical cancer cells is mediated through cell cycle arrest, death receptor, and mitochondrial pathways. Fundam. Clin. Pharmacol. 2013, 27, 581-592. [CrossRef]

76. Hermawan, A.; Meiyanto, E.; Susidarti, R.A. Hesperidin increase cytotoxic effect of doxorubicin in MCF-7 cells. Indones. J. Pharm. 2010, 21, 8-17.

77. Putri, H.; Nagadi, S.; Larasati, Y.A.; Wulandari, N.; Hermawan, A. Cardioprotective and hepatoprotective effects of Citrus hystrix peels extract on rats model. Asian Pac. J. Trop. Biomed. 2013, 3, 371-375. [CrossRef]

78. Shukla, K.; Sonowal, H.; Saxena, A.; Ramana, K.V. Didymin prevents hyperglycemia-induced human umbilical endothelial cells dysfunction and death. Biochem. Pharmacol. 2018, 152, 1-10. [CrossRef]

79. Scalbert, A.; Manach, C.; Morand, C.; Rémésy, C.; Jiménez, L. Dietary Polyphenols and the Prevention of Diseases. Crit. Rev. Food Sci. Nutr. 2005, 45, 287-306. [CrossRef]

80. Orallo, F.; Alvarez, E.; Basaran, H.; Lugnier, C. Comparative study of the vasorelaxant activity, superoxide-scavenging ability and cyclic nucleotide phosphodiesterase-inhibitory effects of hesperetin and hesperidin. Naunyn-Schmiedeberg's Arch. Pharmacol. 2004, 370, 452-463. [CrossRef] [PubMed]

81. Orallo, F.; Camiña, M.; Alvarez, E.; Basaran, H.; Lugnier, C. Implication of cyclic nucleotide phosphodiesterase inhibition in the vasorelaxant activity of the citrus-fruits flavonoid (+/-)-naringenin. Planta Med. 2005, 71, 99-107. [CrossRef]

82. Lee, M.-K.; Moon, S.-S.; Lee, S.-E.; Bok, S.-H.; Jeong, T.-S.; Park, Y.B.; Choi, M.-S. Naringenin 7-O-cetyl ether as inhibitor of HMG-CoA reductase and modulator of plasma and hepatic lipids in high cholesterol-fed rats. Bioorg. Med. Chem. 2003, 11, 393-398. [CrossRef]

83. Kaul, T.N.; Middleton, E.J.; Ogra, P.L. Antiviral effect of flavonoids on human viruses. J. Med. Virol. 1985, 15, 71-79. [CrossRef]

84. Vikram, A.; Jesudhasan, P.R.; Jayaprakasha, G.K.; Pillai, S.D.; Jayaraman, A.; Patil, B.S. Citrus flavonoid represses Salmonella pathogenicity island 1 and motility in S. Typhimurium LT2. Int. J. Food Microbiol. 2011, 145, 28-36. [CrossRef]

85. Vikram, A.; Jayaprakasha, G.K.; Jesudhasan, P.R.; Pillai, S.D.; Patil, B.S. Suppression of bacterial cell-cell signalling, biofilm formation and type III secretion system by citrus flavonoids. J. Appl. Microbiol. 2010, 109, 515-527. [CrossRef]

86. Shetty, S.B.; Mahin-Syed-Ismail, P.; Varghese, S.; Thomas-George, B.; Kandathil-Thajuraj, P.; Baby, D.; Haleem, S.; Sreedhar, S.; Devang-Divakar, D. Antimicrobial effects of Citrus sinensis peel extracts against dental caries bacteria: An in vitro study. J. Clin. Exp. Dent. 2016, 8, e71-e77. [CrossRef]

87. Apraj, V.D.; Pandita, N.S. Evaluation of Skin Anti-aging Potential of Citrus reticulata Blanco Peel. Pharmacogn. Res. 2016, 8, 160-168. [CrossRef]

88. Bencheikh, N.; Elbouzidi, A.; Kharchoufa, L.; Ouassou, H.; Alami Merrouni, I.; Mechchate, H.; Es-Safi, I.; Hano, C.; Addi, M.; Bouhrim, M. Inventory of Medicinal Plants Used Traditionally to Manage Kidney Diseases in North-Eastern Morocco: Ethnobotanical Fieldwork and Pharmacological Evidence. Plants 2021, 10, 1966. [CrossRef]

89. Murata, K.; Takano, S.; Masuda, M.; Iinuma, M.; Matsuda, H. Anti-degranulating activity in rat basophil leukemia RBL-2H3 cells of flavanone glycosides and their aglycones in citrus fruits. J. Nat. Med. 2013, 67, 643-646. [CrossRef]

90. Kawahata, I.; Yoshida, M.; Sun, W.; Nakajima, A.; Lai, Y.; Osaka, N.; Matsuzaki, K.; Yokosuka, A.; Mimaki, Y.; Naganuma, A.; et al. Potent activity of nobiletin-rich Citrus reticulata peel extract to facilitate cAMP/PKA/ERK/CREB signaling associated with learning and memory in cultured hippocampal neurons: Identification of the substances responsible for the pharmacological action. J. Neural Transm. 2013, 120, 1397-1409. [CrossRef] 
91. Knekt, P.; Kumpulainen, J.; Järvinen, R.; Rissanen, H.; Heliövaara, M.; Reunanen, A.; Hakulinen, T.; Aromaa, A. Flavonoid intake and risk of chronic diseases. Am. J. Clin. Nutr. 2002, 76, 560-568. [CrossRef]

92. Benayad, O.; Bouhrim, M.; Tiji, S.; Kharchoufa, L.; Addi, M.; Drouet, S.; Hano, C.; Lorenzo, J.M.; Bendaha, H.; Bnouham, M.; et al. Phytochemical Profile, $\alpha$-Glucosidase, and $\alpha$-Amylase Inhibition Potential and Toxicity Evaluation of Extracts from Citrus aurantium (L) Peel, a Valuable By-Product from Northeastern Morocco. Biomolecules 2021, 11, 1555. [CrossRef]

93. Frydman, A.; Weisshaus, O.; Huhman, D.V.; Sumner, L.; Bar-Peled, M.; Lewinsohn, E.; Fluhr, R.; Gressel, J.; Eyal, Y. Metabolic Engineering of plant cells for biotransformation of hesperedin into neohesperidin, a substrate for production of the low-calorie sweetener and flavor enhancer NHDC. J. Agric. Food Chem. 2005, 53, 9708-9712. [CrossRef]

94. Macheix, J.J.; Fleuriet, A.; Sarni-Manchado, P. Composés Phénoliques dans la Plante-Structure, Biosynthèse, Répartition et Rôles. In Les Polyphénols en Agroalimentaire; Sarni-Manchado, P., Cheynier, V., Eds.; Lavoisier: Paris, France, 2006; p. 398.

95. M'hiri, N.; Ioannou, I.; Ghoul, M.; Mihoubi, B.N. Phytochemical characteristics of citrus peel and effect of conventional and nonconventional processing on phenolic compounds: A review. Food Rev. Int. 2017, 33, 587-619. [CrossRef]

96. Al-Qudah, M.A. Inhibition of Copper Corrosion by Flavonoids in Nitric Acid. E-J. Chem. 2011, 8, 326-332. [CrossRef] 